\title{
PLACE OF THE ELDERLY AND DIVERSITY OF THEIR LIFE SITUATION IN TODAY'S SOCIETY
}

\section{MIEJSCE OSÓB STARSZYCH I ZRÓŻNICOWANIE ICH SYTUACJI ŻYCIOWEJ W DZISIEJSZYM SPOŁECZEŃSTWIE}

\author{
${ }^{1}$ Department and Clinic of Geriatrics of the Nicolaus Copernicus University in Torun \\ Collegium Medicum in Bydgoszcz \\ ${ }^{2}$ students Collegium Medicum in Bydgoszcz
}

\begin{abstract}
Su m m a ry
According to GUS data of December 2014, the share of the population aged 65 years and above in the total population of Poland in 2013 was $14.7 \%$ (every seventh citizen of the country). Forecasts for the upcoming years are as follows: in $2020-18.9 \%$, in $2035-24.5 \%$ and in $2050-$ $32.7 \%$. The percentage of people aged 65 years and older is called aging of the population factor. Among these people, $35.81 \%$ are rural residents. In the cities, elderly population accounts for almost $16 \%$ of the whole population; in rural

slightly more than $13 \%$ of the population. However, it is expected that due to growing migration, in a short time, most seniors will live in cities. As a result, the share of the elderly will exceed $30 \%$ in rural areas, while in the cities it will come close to $35 \%$. The majority of the elderly are women (approx. 61\%). This is due to the higher mortality of men women now live five years longer on average. Forecasts indicate that in 30 years every third citizen of our country will belong to the group of older people $[1,2]$.
\end{abstract} areas this number is significantly smaller and accounts for

\section{Streszczenie}

Według danych GUS-u, z grudnia 2014 roku, udział ludności w wieku 65 lat i powyżej w populacji ogółem w Polsce wyniósł w roku 2013 - 14, 7 \% (co siódmy obywatel kraju). Prognozy na kolejne lata przedstawiają się następująco: w 2020 - 18,9\%, w 2035 - 24,5\%, a w 2050 $32,7 \%$. Odsetek osób w wieku 65 lat i więcej jest nazywany współczynnikiem starości danej populacji. Wśród tych osób $35,81 \%$ to mieszkańcy wsi. W miastach ludność w starszym wieku stanowi prawie $16 \%$ populacji; na terenach wiejskich mieszka ich zdecydowanie mniej i stanowią niewiele ponad

Key words: life situation, elderly, society

Stowa kluczowe: sytuacja życiowa, osoby starsze, społeczeństwo

Life situation of the elderly is very diverse. They live with families, alone or in all types of social welfare facilities. Most of the elderly live in
13\% mieszkańców wsi. Przewiduje się jednak, że na skutek rosnącej migracji, w niedługim czasie większość seniorów będzie zamieszkiwała w miastach. W rezultacie udział osób starszych przekroczy $30 \%$ na obszarach wiejskich, natomiast w miastach zbliży się do $35 \%$. Większa część osób starszych jest płci żeńskiej (ok. $61 \%$ ). Wynika to $\mathrm{z}$ wyższej umieralności mężczyzn - kobiety żyją dziś przeciętnie o 5 lat dłużej. Prognozy wskazują, że za 30 lat już co trzeci obywatel naszego kraju będzie należał do grupy osób w starszym wieku [1, 2].

households (nearly 70\%). Approx. 22\% live alone. The study POL-13 SENIOR distinguished 13 forms of family life, of which approximately $91 \%$ consisted of 
six leading subtypes: a person living alone $22 \%$; living as marriage $32.2 \%$, married couples living with children $8.5 \%$; a family composed of elderly and her/his children $8.6 \%$; married couples living with children and grandchildren $9.9 \%$; family consisting of elderly, her/his children and grandchildren of $10.1 \%$. Other forms (and unknown) accounted for $8.7 \%$. Among older people, marriage happens in men $(47 \%)$ twice as often as in women $(23 \%)$. Older women more often than men are not involved (single). These are mainly widows [3].

In cities, in over $50 \%$ of households, elderly person lives together with marriage having children, while in rural areas the figure is over $75 \%$. In the countryside, you can also meet many multigenerational families, where four (or even more) generations live under one roof. The data is confirmed by the results of POLSENIOR study conducted in 2007-2010 [2, 3].

Another living environment of the elderly are all kinds of social welfare institutions. At the end of December 2011, the country had 782 active social welfare homes [4] of total population equalled to about 76 thousand people: the elderly, the chronically ill, mentally, physically and intellectually disabled. This included: for the elderly - 188 houses for 13071 places; for people with chronic somatic diseases - 219 houses for 24715 places; for chronically mentally ill 147 houses for 18366 places; for adults with intellectual disabilities - 146 houses for 14360 places; for children and young people with intellectual disabilities - 104 houses for 8372 places; for the physically disabled - 11 houses for 1342 seats.

Data from other authors is as follows: for the year 2011 - 799 active DPS /social assistance house/: 595 state houses, 204 private houses. In 2012, respectively - 802, including 594 public and 208 private houses. On average 1 places accounted for approx. 480 inhabitants. To illustrate the degree of meeting the needs of persons waiting for their placement in the nursing homes, we present the percentage as of 31.12.2012, which amounted to $61.9 \%$ [5].

Poland is a country with strong family ties. Although the observed phenomenon of slow relaxation and expansion of the group of people living alone, research shows that intergenerational ties are still strong in Polish families [2, 6].

Gerontologists stress that family contacts, mutual reflectivity of the family and providing assistance, play a very important role in the lives of the elderly. They are a source of emotional balance, and sometimes even mental health balance, and constitute a fundamental prerequisite for adaptation to social life. Different types of family behaviours are the most common form of interpersonal behaviours [7].

Also Orzechowska [8] confirms that the best ally of the period of old age should be a family. It is required, in a natural as well as in a legal way, to help and care for an elderly person, that is a parent, grandmother or grandfather. Not to challenge is the fact that loving, good, cordial and attentive family is the environment that is perfect to support and assist an elderly man in all sorts of situations difficult for him.

The family, which is the reference plane for man at every stage of development, fulfils a particularly important role in the life of a senior. Contacts with family members may be the only type of social relations linking an elderly person into society. They can stimulate or inhibit the growth of human social participation [9].

The family can make its older members feel useful and involved in everyday life, which slows down the appearance of decrepitude and does not allowed them to resignation, social isolation, and lower self-esteem [10].

According to Wierzba, family is of fundamental importance for the period of old age, because it is a natural plane on which a majority of execution, developmental and emotional processes take place. It is also a point of support for an aging man when he finds there respect and understanding and receives help, support and care. An elderly person may also feel the satisfaction of performing the role of the grandfather or grandmother. This role is an important source of gratification and creates a new status in the family hierarchy. Acting as a grandmother or grandfather also gives the feeling of being useful, even indispensable for their grandchildren, children and their spouses [11].

However, life situations are different and not every elderly person can rely of the family's help and support. Sometimes a lonely, ailing, elderly person in need, is forced to seek help in all sorts of social assistance centres. It will never replace the help of the loved ones, but existing forms of social support meet the health, material and social needs of older people $[8,12,13]$.

Every year, the number of social welfare homes in Poland increases; however, the number of people waiting for a place increases as well. On average, inclusion of this type of institution means waiting for about a year or two. For many older people, 
particularly those living alone, deprived of their families, sick and dependent, with very low incomes, welfare institutions are the only place where you can spend the rest of their lives. People who cannot count on family support, who are deprived of job opportunities and are not able to function in their environment despite different available services, can apply for a place in a social welfare home.

Adapting to institutional care for many elderly people is very difficult, but still possible. Factors such as health status, personality, intelligence, activity play an important role in this process. A lot of people do not have a high opinion on nursing homes, which often arises from a desire to remain in familiar surroundings, close relatives and friends. The most negative feelings towards such institutions are caused by the loss of independence and a sense of conviction that living in such place is a formal proof of approaching death. Older people are afraid that when placed in a nursing home they will be rejected and forgotten by their children. Often they have not heard anything positive about this type of places, so it is not surprising that they do not want to be there. However, there is a positive side to stay in social assistance centres: immediate health care, regular meals, various forms of organized activity, company.

One of the problems of older people living in nursing homes is their low activity compared to people living in their own homes. A syndrome so-called "institutionalization of life" appears. As a result of being in such places, in the functioning of residents appears dependency and learned helplessness, resulting in cognitive, affective and functional deficits. Their behaviour is characterized by passivity, they live according to a planned rhythm of the day. There are automatic behaviours and general apathy. Sometimes they are no longer interested in their appearance, withdraw from social relations and their mental state deteriorates. In some people it is a reaction to encountered in nursing homes impersonal relationships, less individual treatment by staff. Poor well-being may also result from loss of privacy. According to Foy and Mitchell, deterioration of mental and physical condition is accompanied by realizing the lack of control over oneself and the environment $[2,6,14]$. It is important to not relieve the residents in all activities and expect them to perform certain, even small steps. They need encouragement, stimulus from the outside, support and words of encouragement. If the older person are moved away, treated as unnecessary and useless, they stop to be active. The employees of social welfare homes argue that the most active among the inhabitants are by people with higher education and farmers.

Well-being and economic status, in addition to the place of residence, also influence the current life situation of the elderly [15].

Health, both subjective and objective, correlates with a sense of pleasure and satisfaction with life that determine the state of human mental balance. However, for the well-being of particular importance is somatic health in subjective aspect. Subjective assessment of health status can be determined by demographic factors, i.e. age and gender. Over the years, percentage of people assessing their health as good is decreasing, while there is a growing number of people who say their health is bad. Men more positively than women assess their own health $[9,16]$.

According to GUS, in 2014 the average income of a pensioner in Poland was 2 117.35 PLN (1 736.22) and a retiree - 1581.47 PLN (1296.80). According to data from 2010 own financial situation is assessed as very good by less than $1 \%$ of the respondents and they are included in a group of $7 \%$ of respondents claiming to "live well" (financially can afford a lot, though not all). The average standard of living is declared by $46 \%$ of respondents, and $41 \%$ assess it as modest. $6 \%$ of respondents report a very bad economic situation of elderly people $[17,18]$.

The results of research into the life situation of the elderly in Poland at the beginning of the twenty-first century show that old age is not easy for them. Such a state is affected by: the loneliness and sense of isolation, deteriorating health with age as well as the difficult economic situation.

\section{SUMMARY}

The number of people aged 65 and older is growing and will continue to grow in the perspective of 35 years. This growth will be very dynamic since it will include people born in the 50s (the most numerous throughout the post-war period), as well as in the $60 \mathrm{~s}$ of last century. For example: in 1955 almost 600 thousand people were born and in the 60's approx.. 540-460 thousand were born in each year - in recent years less than 400 thousand children have been born annually. Additionally, you should assume that life expectancy will increase gradually in favour of both 
the number and proportion of the elderly population in the total Polish population.

\section{REFERENCES}

1. GUS listopad 2014, Sytuacja demograficzna osób starszych i konsekwencje starzenia się ludności Polski w świetle prognozy na lata 2014-2050.

2. Stanisławski P.: Niewesołe życie staruszka. Integracja, 2002, 1, s.10-19.

3. Szatur-Jaworska B.: Sytuacja rodzinna i więzi rodzinne ludzi starych i osób na przedpolu starości. W: (red.) Więcek A., Błędowski P.: Aspekty medyczne, psychologiczne, socjologiczne i ekonomiczne starzenia się ludzi w Polsce. Termedia Wydawnictwa Medyczne, Poznań 2012, s. 419-448.

4. Grubasińska Z.: Domy pomocy społecznej w Polsce. Centrum Rozwoju Zasobów Ludzkich, Warszawa 2013.

5. Regionalny Ośrodek Polityki Społecznej w Białymstoku Obserwatorium Integracji Społecznej. Opieka nad osobami niesamodzielnymi na przykładzie funkcjonowania Domów Pomocy Społecznej w województwie podlaskim. Białystok 2013/2014.

6. Susułowska M.: Psychologia starzenia się i starości. PWN, Warszawa 1989.

7. Olejniczak P.: Wsparcie społeczne i jego znaczenie dla osób starszych. Pielęgniarstwo i zdrowie publiczne. 2013: 3 (2) s. 183-188.

8. Orzechowska G.: Aktualne problemy gerontologii społecznej. Wyższa Szkoła Pedagogiczna, Olsztyn 1999.

9. Tokaj A.: U progu starości. Wydawnictwo Eruditus, Poznań, 2000.

10. Rembowski J.: Psychologiczne problemy starzenia się człowieka. PWN, Warszawa - Poznań 1984.

11. Wierzba. A.: Starzenie się a problem utraty. Psychoterapia, 1998, 3, s. 21-29.

12. Pikuła N.: Senior w przestrzeni społecznej. Borgis, Warszawa 2013.

13. Węgrzyn K.: Miejsce ludzi starszych w zmieniającej się rodzinie - zarys problemu. Ann Med. Siles. 2002, s. $125-134$.
14. Turner J., Helms D.: Rozwój człowieka. Warszawa: Wydawnictwa Szkolne i Pedagogiczne S.A., Warszawa 1999.

15. Kaplan G.A., Shema S.J., Leite C.M.: Socjoeconomic determinants of psychological well-being: the role of income, income change, and income sources during the course of 29 years. Ann Epidemiol. 2008, 18, s. 531-537.

16. Zych A.A.: Człowiek wobec starości. Interart, Warszawa 1995.

17. GUS 2014, Emerytury i renty w 2014 roku.

18. Obraz typowego Polaka w starszym wieku. CEBOS, Warszawa 2010.

Address for correspondence:

Katarzyna Porzych

Department and Clinic of Geriatrics

of the Nicolaus Copernicus University in Torun

Collegium Medicum in Bydgoszcz

85-094 Bydgoszcz

M. Curie-Skłodowskiej 9 Street

tel. (52) 585-49-00

fax (52) 585-49-21

e-mail: kikgeriat@cm.umk.pl

Anna Polak-Szabela (e-mail: annapolak1979@wp.pl)

Kajetan Hadzik (e-mail: kajetanhadzik@gmail.com)

Martyna Porzych (e-mail: martyna_porzych@wp.pl)

Kornelia Kędziora-Kornatowska

(e-mail: kikgeriat@cm.umk.pl)

Received: 15.03.2015

Accepted for publication: 8.06.2015 